\title{
医, 獣医学研究に用いられる実験動物の問題点
}

\author{
猪貴 義*
}

\section{1. が国の現状}

医学, 薬学, 獣医学などの研究分野において, 最近, 実験動物に対する関心が非常に高まってきている．欧米 などの諸外国を廻って帰国された多くの研究者の報告汇 よると, 最近数年間に打ける著しい変化の 1 つに, 実験 動物に対する関心と, 各種研究機関に打ける実験動物施 設の拡充整備をあげている.

これら一連の現象は, わが国に掠いても例外ではない が, 医学, 薬学, 獣医学の研究の根底をなす動物実験に 対する過去の反省と, 残された研究 (癌, 代謝病, 老人 病, 体質, その他など）が穾験に使用する動物の条件を 考慮することなしには解析を進めることが不可能な段階 にきているためとみられる。

わが国に和いては, 1951年に, 遺伝育種学, 癌, 臨床 医学, 細菌, ウイルス学関係者の協力の下に, 実験動物 研究会が設立され, 研究機関誌として “実験動物巢報” (現在は実験動物) を発行し, 展示会や研究会を開催し て,わが国の実験動物の推進に当ってきている.

実験動物施設としては, 文部省が 1949 年に, 静岡県 三島市の国立遺伝学研究所に㨟いて系統保存のためのマ ウスの飼育室を建て, ついで, 1956 年に, 北大理学部 にラットの系統保存のための飼育室を完成し, さらに同 年, 東京大学伝染病研究所飞実験動物生産施設を建設し た.これらに続いて, 国立大学や国立の研究機関, 民間 の製薬会社などでも純系動物飼育室が建設され, 近交系 動物の繁殖に乗り出すようになってきた。農林省家畜衛 生試験場では, 1961 年, 1962 年の両年にわたって純系 動物飼育室 (広さ $280.84 \mathrm{~m}^{2}$ ) の建設を行なった。

各種研究機関で純系動物飼育室が設立された主な理由 は, 従来から動物業者によって供給されてきた素性の明 らかでない動物 (系統, 年令不明, 栄養不良, 内部寄生 虫の多い, 病原微生物の感染の抢そ机のある動物) の使 用を止めて，それぞれの研究機関执いて，系統の明ら かな, 寄生虫や病原微生物のない, 健康動物を自らの管理 の下に拈いて生産し, これらの動物を研究者に供給しょ らとする試みであった。

1960 年, 日本医学会は動物実験現状調査会を組織し て, わが国に括ける動物実験に関する広範囲の現状調 查1 を行なったが, それらの調査からいくつかの問題点 を引き出して考兄てみたい。

* 農林省家畜衛生試験場, 研究第 1 部

日獣会誌 19 (1966)
実験動物施設 実験動物の施設については大学関係で 中央施設のあるもの 54 , ないもの 11 , その中央施設で 動物の生産を行なっているもの11, 国立研究所では, 中央施設のあるもの 12 , ないもの 2 , その中央施設で 動物の生産を行なっているもの 5 , 製薬会社では中央施 設として報告された 6 施設のうち 4 施設が動物の生産を 行なっている.

実験動物の入手経路 入手経路としては，1．自家生 産, 2. センター生産, 3. 他からの分譲, 4. 委託生産, 5. 業者からの購入, 6. その他に分けられたが, 各動物 のらち, マウス, ラット，モルモットについては業者か らの購入が大部分を占めており, 自家生産は実験動物の 生産センターを持つ施設で行なわれ, 動物種別としては マウス, ラットが多い.

実験動物の使用数 1957年に日本実験動物研究会の行 なった調查では，1956年度に使われた実験動物の数は， マウス 127 万 5 千, ラット 16 万, ウサギ 7 万 2 千, モ ルモット 6 万 8 千, イヌ 2 万 7 千, ネコ 1 万, ニワトり 2 万 3 千, 八ト・ウズラ・十姉妹 4 千, カエル・イモリ ガマ9 万 6 千と報告されている. 1960年の今回の調査の 対象範囲は広くなっているので, この数と比較すること ができないが，1957年の調査との対象部門での比較は可 能である. 今回の調査結果では, マウス 246 万, ラット 35万 3 千, モルモット 12 万 2 千, ウサギ 16 万 5 千, ハムスター・フェレット 5 千, イヌ 4 万 8 千, ネコ 1 万 6 千, サル 5 千, ヒツジ・ヤギ 1 万 3 千, ブタ・ウシ・ ウマ 4 千, 八ト・ウズラ・アヒル・十姉妹 5 千, 鷄卵 283 万 4 千, カエル・イモリ・ガマ 15 万 2 千, その他 となって和り，1957年の調査対象でなかった部門を除い て比較してみると, その使用頭数は著しく増加している ことが明らかである。とく製薬会社では，マウスにお いて 27 万から118万, ラット5万1千から9万8千, モルモット4 千から 3 万 2 千と顕著な増加がみられる。

施設別にみると, マウスの使用数の最も多いのは, 製 薬会社の 118 万(全体の $48 \%$ ) で, その他の研究所 25 万 3 千 $(10.3 \%)$, 大学医学部基礎部門 23 万 2 千 $(9.4$ $\%)$, 大学研究部門 16 万( $6.5 \%)$, 大学医学部臨床部門 15 万 3 千 $(6.2 \%)$ であり, ラットは 35 万 3 千のらち, 製薬会社 9 万 8 千 $(27.7 \%)$, 大学医学部臨床部門 8 万 6 千 $(24.3 \%)$, 基礎部門 6 万 1 千 $(17.2 \%)$ が使用されて いる. モルモットも製薬会社の使用数が最も多く, 12 万 2 千のらち 3 万 2 千 $(26.2 \%)$ である. ウサギは大学医 
学部臨床部門が総数 16 万 5 千のらち 4 万 9 千 $(29.9 \%)$ を占め, イヌも同様総数 4 万 8 千中， 2 万 9 千 $(59.7 \%)$ が大学医学部臨床部門で使用されている.

実験動物の用途 用途別に大別すると, 研究, 検定, 診断，製造，教育々の他に分けられる. 動物種別にみる と, 研究が使用数の $50 \%$ 以上を占めるものは, ラット (74.1\%)， ウサギ $(55.7 \%) ，$ 八ムスター・フェレット $(88.6 \%)$, イヌ $(90 \%)$ ，ネコ $(80.6 \%)$, ワトリ $(79.1$ $\%$ ）である. 製造が使用数の $50 \%$ 以上を占めるものは, サル $(64.9 \%)$, ヒッジ・ヤギ $(74.5 \%)$, 鷄卵 $(94.9 \%)$ などである、検定で特異なことは，八トその他の鳥類が 最高值で $60 \%$ を占めている. 同じく検定に和いてかな りの使用率をもっているのは，モ゙モットの $35.1 \%$ ， ウサギの $28.4 \%$ などである.

各動物種についてみると, マウスは腫瘍, 微生物学関 係にかなり平等に用いられ，ラットは腫瘍, 内分泌, 薬 理学への使用が多い. ウサギとモルモットは薬理学, 微 生物学, 免疫・血清学方面での使用頻度が高い.イヌは 微生物学関係での使用が皆無であり，外科にかなりかた よって使用されている. 循環器, 神経生理の研究にもま た多く使われている。ネコはカエル・イモリ・ガマとと もに生理, 神経方面, あるいは薬理学に重点的に用いら れているのが特異的である。ヒッジ・ヤギ・ブタ・ウマ・ ウシは獣医畜産学に多く使われているが, ブタが栄養の 研究にも多く用いられるのが注目される。八ムスタ一・・ フェレットはその特殊な感受性のために, ウイルスにも っとも多く用いられる。 また腫瑒研究の対象となってい る. 鷄卵はウイルスへの使用が断然多い.

これら項目以外についても詳細な調査結果を発表して いるが，この調查から明らかなことは，各研究部門で赛 験動物の使用頭数が著しく增加してきていること, その 傾向はとくに製薬会社関係に多いこと. 実験動物の供給 状況は, 大学の基礎部門でのマウス, 製薬会社のラット は例外として, 一般業者に依然として依存している割合 の大きいこと, 末た, 研究者側からの動物に対する要求 としては, 一応に精度の高いもの一個体による生物学的 な偏差の少ない動物一を希望している. 大学に打各 施設からはそれぞれの実験例により感受性の高いマウ ス, モルモットの要求, さらに潜伏感染のない動物,

S P F 動物を強く要望している. 実験動物施設としての 要求は, 一般には, 恒温, 恒湿の調節自由な施設の要求 が高いことがあげられる。

これらの実態調査結果かららかがわれることは, 純系 動物施設を有している機関の一部研究者は, 素性の明ら かな動物を使用して研究を進めることができるが，わが 国の研究者の大部分は, 良質の動物供給不足の条件下 で, 旧態依然たる動物実験を繰り返している現状とみる ことができる．ここにわが国の動物実験の問題点があ
り，将来に対する改善の方向が含まれているものと考兄 る.

\section{2. 動物実験に影響する要因}

動物実験というのは, 1 群の動物に処置を加えて, こ れに対する動物の反応から，処置した効果を判定するも。 のである、したがって，動物実験の結果が正確であるた めには，一定の処置に対する反応が常に同一であるよう な条件を見出さなければならない，言いかえれば，実験 結果の再現性が期待できるものでなければならない，同 じマウスであっても, その系統, 性別, 年令ばかりでな. く, その動物の栄養, 飼育管理などによって一定の処置 に対する反応がまちまちになる。また，その動物が寄生 虫や病原微生物なぞを保有しているばあいなぞも実験の 結果に影響のあることは当然である。

最近における動物実験では, 采統の明らかな (genetic; control), 健康な (disease control), 一定の飼育環境, 飼料などの条件 (environmental control) の下で生産さ れ維持された動物を使用することに多くの関心が寄せら， れてきている，そして，これら遺伝的，病的，環境的制． 御条件下にある動物を実験に使用することによって始め， て, 精度の高い, 信頼性のある実駼結果が期待できると みられる。

以下に，実験動物に括沙る遺伝的制御（genetic con-. trol), 病気制御 (disease control), 環境的制御 (environmental control) について述べることにする.

\section{1) 遺伝的制御}

1960年の調查1)によると，わが国に打壮る実験動物の、 系統としては, マウスが最も多く, 外国からの輸入 37 , 国内での分離育成 68 , 計 105 系統，ラットは輸入，国 内分離あわせて 29 ，モルモット 3 ，ウサギ 1 ，ハムスタ ー2 といら数になっている。 また，ニワトリや昆蝢に おいてもいくつかの系統が明らかにされている.

現在，実験動物の遺伝的制御としては，1. 近交系と して維持されている群，2．封鎖集団 (closed colony), として維持されている群，3. 交雑群として維持されて いる群などに分けることができる.

マウスでの命名規約2)によると, 近交系 (inbred strain）というのは，兄妹交配または親子交配を20 代以上 継続している系統, ただし両交配を混用しないこと，ま た親子交配のばあいは, 次代の交配は両親の若い方（後 代のもの）と行ならものと古る．とされている. 近交系 の命名には，口ーマ字体の大文字であらわすことになっ ている (例, $\mathrm{C}_{3} \mathrm{H}, \mathrm{C}_{57} \mathrm{BL}, \mathrm{DBA}$ ). 他の動物でもマウス のばあいと同様の交配方法で近交系の作出が行なわれて いる. 近交系の確立のために, 近交世代 20 代を必要と する理由は，マウスやラットなどの上らに 20 対の染色 体を持っているものでは, その過程に全く選択がないも， 
のとすれば，扣上そ20 代の近親交配を重ねることによ って，99.6\%の遺伝子が同種対立因子から成ると推定さ れるためである.

封鎖集団群というのは, 一定の集団内のみで繁殖が継 続されている群で, 一般には, 近交系に起源をもつが, 兄妹交配によらない維持集団と, 起源が近交系によらな いが， 5 年以上，一定の集団内の久で繁殖の継続されて いる群（例，ICR，gpc, dd 系の一部)に分けられる：な 招, 封鎖集団群の集団の大きさには特別の制約は決めら れていないけれども, 極端て小さい集団は近親交配にな るので, 望ましくなく, 常時繁殖用に保有している頭数 は 500 匹以上であることが望ましいとされている. 動物 実験に打ける封鎖集団群の動物は，ホルモン, Vitamin, 、制癌剤, ワクチン関係（安全, 力洒試験）など一時に多 数の動物を使用する検定などにおいて利用価值が高いと みられている.

交雑群というのは, 系統間の雑種で, 近交系間の交雑 第 1 代のもの, 近交系之封鎖集団群の間の交雑第 1 代の るの, 封鎖集団間の交雑第 1 代のもの, 交雑第 1 代以外 の交配法のもの $\left(\mathrm{F}_{2}\right.$, back-cross, 3 原交配, 4 原交配な ぞ)などが含まれる. 交雑群で実験動物としてとくに問 題となるのは, 系統間交雑 $\mathrm{F}_{1}$ の動物である.この $\mathrm{F}_{1}$ は 成長や繁殖能力に打いて雑種強勢 (heterosis) を示すだ 吇でなく, 封鎖集団群と同様にホルモンやVitamin の 測定，また制癌剤の選別などに多く使用される傾向にな ってきていることである.

近交系，封鎖集団群， $F_{1}$ はそれぞれ実験動物の価值 を有しているが，その使用目的からみて，本質的に区別 すべきものと考觉る。ここでは, 動物実験における近交 系動物の価値について考えてみたい。

動物実験において動物の系統が重要視される理由は, 系統によって，それぞれ特有の遺伝的素質をもっている ために, 細菌やウイルスに対する感受性や抵抗性, 癌の 発生や增殖, あるいは薬物に対する反応性などに系統特 有の反応を示すことが明らかにされている．たとえば, マウスには乳癌のよく発生する系統 $\left(\mathrm{C}_{3} \mathrm{H}\right)$ b无れば, また全く発生しない系統 $\left(\mathrm{C}_{57} \mathrm{BL}\right)$ もある。また, 細菌 やウイルスの增殖にしても, 薬物の反応にしても, ネズ ミの素質によっては結果は決して同じでない事実が知ら れている. 欧米の学会に扎いては, いち早く実験動物, とくにマゥス, ラットなどの系統が重要視され, 特定の 研究をするにはその研究目的に応じて系統のはっきりし た近交系動物を使用しなければ，その研究結果は論議の 対象とならないとさえいわれる活ど，実験動物の遺伝的 素質については研究者の関心が深いのである.

1963年に, 田嶋3 はわが国の各研究機関, 研究者が維 持している動物種ならびに系統についての調査結果を報 告している.マウスでは外国からの輸入系統として 42
系統，わが国で分離育成された系統として 86 系統，計 128 系統, ラットでは 29 系統, モルモット6 系統, ウ サギ 2 系統, 八ムスター2 系統, その他の小動物, トリ 類, 昆虫類, その他などについてあげ, 系統名, 呼び 名, 遺伝子, 由来, 特性, 輸入経路, 維持機関名, 文献

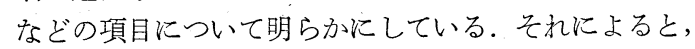
多数の動物種, 系統において, すでにとの特性が明らか にされているものもあるが，な拉，多くの系統に执いて は, その特性が十分に明らか汇されず，動物実験に和け る使用目的のはっきりしないものが多い。したがって, わが国において維持されている多くの動物種, 系統がい かなる研究に適するかどうかの特性の検討は実験動物の 分野では急を要する重要な課題といわなければならな い.とくに，わが国の研究者によって長年月の期間にわ たって分離育成された系統の特性つけである.

\section{2) 病気制御}

健康な動物, それはふつらの病気はもち万ん, 感染病 のない動物を意味するが，各種実験動物には，それぞれ 個有の多くの感染が存在する。 そしてとくに厄介なの は, いわゆる潜在感染である。潜在感染を起こす伝染病 としては, マウスでは, サルモネラ, エクトロメリヤ, 幼子下痢, TYZzER 氏病, ウイルス性肺炎(HVJなど), PPLO, コリネ症などの多数の伝染病が知られているが, ミットでは比較的少なく, サルモネラ, 各種肺炎, P P LO中耳炎など, モルモットでは溶連菌症, サルモネ ラ, 仮性結核症, 肺炎, 下剠症など, ウサギではコクシ ジウム症, 仮性結核症, スナッフル, 下痢症などが知ら れている。

以上あげたような伝染病は容易に慢性化し, 潜伏感染 の形となって広がること, 潜伏感染化して発見が困難と なるため, 根絶ができず, 新しい世代が生まれるごと に，㐫るいは飼養管理の行き届かないときなどに流行を 起こし, 生産の障害となったり, 実験処置によって誘発 発病して動物実験の支障を来すことである.

世界外国の実験動物の研究者は, これらの潜伏感染を 排除する方策を確立するために長年月にわたって努力し てきたが，それらの努力は，一部の感染病に対しては有 効であったが，乙かし多くのものは実ることなく終って いる。午して, 現実には“健康な”之いう言葉を自然感 染のなるべく少ない，しかもその程度がなるべくはっき りしたという内容にとどめざるをえないのが実情であっ た、ところが，無菌動物 (Germ free animal) を作出す る技術を応用して，いわゆる S P F 動物” (Specific pathogen free animal) が作り出されるようになった. それは，その動物滰通にみられる自然感染を排除する 可能性を示している.ここにはじめで自然感染のない” 1 健康動物の生産が可能になってきたわけである4). ( S P F 動物についての詳細は田嶋嘉雄4)を参照されたい).

日獣会誌 19 (1966) 
現在, 諸外国に括汗る傾向としては, 実験動物は急速 KS P F $\rightarrow$ Gnotobiote $\rightarrow$ 無菌動物 (Germ free animal) の方向に向ってきている.

S P F 動物というのは, 一般には, 娃娠末期におい て, 子宮切断, または帝王切開によって取り出された 後, 無菌的な人工乳, 人工哺乳によって育成され, 一定 の規制された環境（無菌的ではないが）で維持されてい る動物であり，とくに指定された微生物や寄生虫のない 動物のことを指している，ただし，指定されていない微 生物, 寄生虫はあってもか子わないとされている.

Gnotobiote とは, 生体内に保有するすべての微生物 （検出可能な範围で）が明らかなもので, 子宮切断, 帝 王切開や，その後の育成には無菌的な条件で維持され る.

無菌動物とは作出過程はS P F と同様であるが，その 作出, 育成方法は厳密な無菌的な条件下で維持されてい る動物で, 検出しらるすべての微生物ならびに奇生虫を もたない動物である.わが国に㨟いては, 名古屋大学の 宮川教授, 千葉大学の田波教授らによって古くから無菌 動物の開発研究が行なわれてきた5,6). また, 農林省家畜 衛生試験場では, 最近, S P F 豚の作出认成功し, この 面での開発研究に期待が寄せられている.

健康動物のうちには, 病気や感染以外寄生虫の問題 子当然含委孔る. 寄生虫や原虫は微生物の上万に実験動 物の間に流行病を起こしたり，実験中の死因となるょう なことが少ないために，比較的軽視されがちであるが， 肝蛭感染の常在するともい学る市貼のラットが肝機能の 検查に使われたり，回虫感染動物を使ったために回虫の 毒素説が展開されたことを考学ると，これまた重要な問 題である.

寄生虫駆除についての試みもいろいろ7,8) あるが，む しろ問題となるのはコロニー維持の方法にあるようであ り，大きいコロニーを寄生虫のいない状態に保持するに は，少なくとも S P F 動物生産に準ずる方法をとらねね゙ ならない。

\section{3）環境制御}

一定の環境が動物実験において必要である理由は, 動 物の栄養や, 温度, 湿度, 照度, 音響, 換気のような動 物管理条件，また，生物社会的な飼育条件などが動物実 験の成績に影響してくるためである.

動物は常に外部環境の変動に応じて, 内部環境として の生理機能を調節する役割を持っている. これら適応力 の有無が生物と無生物の大きく区別さ机る点でもある。

したがって，外部環境の変動が動物の生理反応に影響を 与えることは当然考えられる.

動物実験において，実験動物の飼育する飼料がその成 績に重大な影響を与えることは多くの研究者によって報 告されている，栄盖に欠陥のある飼料は動物化種々の生
理的，病理的変化をひき招こす，たと兄ば，体重，繁 殖, 泌乳などに生理的変化や血液, 畉, 精子, 骨, 神 経，眼などに病理的変化がみられることが報告されてい る.

また，飼料の量や質が感染実験の成績に影響すること も知られている9,10)。 また, 中野11はラットの性周期と 飼料の関係について検討しているが，長期間飼いならさ れた飼料から質の異なった飼料に転換すると, 動物は容 易に変化した飼料に順応できない性質を持っていること を報告している.

現在, わが国に执いては, 実験動物用として, 動物種 別, また実験用, 繁殖用, 離乳用, 特殊繁殖用などの用 途別の固形飼料が市販されているので，全国的に同じ栄 湌レベルでの実験を行な光るような条件になりつつあ る.しかしながら，動物の系統によって栄養要求が異な るので, 市販飼料の給与ではな扔不満足の系統もある. したがって，この面での改善は今後に残されている問題 の1つである。

飼育室内条件として温度, 湿度, 照度, 音響などがあ

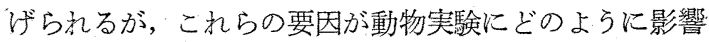
するかといら詳細な検討は今までのところ十分に進んで いない現況である。しかし，最近における環境生理分野 の研究は, この面にも積極的に取り組んできている.

ただ，動物実験において問題となるのは，実験結果に 影響を与兄る条件の種類や質の程度について十分に娭討 されるごとである，さきにも述べたように，動物は外部 環境の変動に対して適応力を持っているが，外部環境の 変動に対しての生体反応の分散の程度が問題となる。“環 境条件の中には, 生体反応值の分散に大きく影響するも のもあれば，あまり影響のないものもあるに違いない。 また動物側に怙いても近交系や雑種, $F_{1}$ などの動物の 遺伝的な違いによって環境変動に対する適応力の違いも 明らかにされてきている12,13)。

最近に打梳験動物施設は空気調節装置 (air-conditioner)をそな元, 温度（最適温度はサルを除いて 22 $23^{\circ} \mathrm{C}$ ), 湿度（最適湿度 $50 \%$ ) が人為的倜節でさるほ か，照度，音響（40〜50 ホンが望ましい)なぞでも制御 可能の施設になってきている.

そのほか, 動物の飼育用具 (ケージ, 給慨器, 給水瓶, 飼育棴）などにも改良が進み, 全国的に規格化された条、 件で試験が行なわれるようになってきている.

なお，今までに比較的検討されてこなかった環境の 1 つに, 動物相互間の関係から発生する動物社会的な環境 があげられる．動物が群居するばあい動物社会が構成さ れるが, 動物の社会的順位や行動が生理機能の変化や実 験の成績に影響を及代すことが次第に明らか炕されてき た. 癌の発生率がケージ内のマウスの数と関係のあるこ と14や，ラットの結核の感受性に及注す群居の影響が倠 
と雄とで違うことなどが報告されている15).

\section{3. 打わり}

以上, 医, 獣医学研究に用いられる実験動物のわが国 の現状，または，動物実験において影響すると考えられ る要因の概略について記したが，日本医学会の動物実験 現状調査にもあるように, わが国の動物実験の現状は古 い時代に比べて著しく改善された点の多いことを認め る.しかしながら, 研究機関によっては, 実験動物の大 部分を動物業者に依存して, 旧態依然たる実験をくりか えしている現状のあることも認めなければならない。こ れらは速に解決されなければならない点である。

動物実験に影響する要因として, 遺伝的制御, 病気制 御, 環境的制御の 3 つの面より検討したが，これらの問 題は 1966 年の実験動物研究会のシンポジュウム課題で もあり，いずれも実験成績に影響する内容を含んでいる とみられるので, 今後とも引続き検討し, くりかえし, くりかえし，討論が行なわれてゆくものと考える.

なお, 最後に実験動物之獣医, 音産学の関係について 述べてみたい，始めに記したように，わが国に拈ける寒 験動物研究会の成立過程は, 遺伝学, 育種学, 癌, 臨床 医学, 細菌学, ウイルス学関係者の総意によって設立さ れたものであり, 専門別には, 主に医学, 薬学, 獣医 学, 畜産学, 理学などのメンバーによって構成されてい る会である。一般には, “動物実験”之“実験動物”と いう2つの側に分けられているが，前者は動物を使って 実験する使用者側にある、また後者は実験動物そのもの の研究, または生産, 供給する側に立っている. 動物実 験には必然的に動物の量や質が関係してくるし, 実験動 物は実験者に使用されることによって始めてその価値を 生産するといら関係から, 両側の informationの交換な しにはその進展が望めないような関係立っている。

1959年, 日本学術会議主催の “医学生物学領域におけ る実験動物シンポジゥム゙に扑いて, 実験動物の世界各 国の現状について講演した安東実験動物研究会理事長は 結語として, “医学研究の基本的要約である実験動物の 進歩は遺伝学, 育種学, 獣医学, 動物学など各方面の研 究成果を実際の動物生産に具体化してゆくところにあ る.したがゥて, これら各方面の研究と, 実験動物の生 産ならびに実験動物に関係のある技術方面の産業, さら に医学自体から出される要求とが，互いに影響しあいな がら協力して進展してゆくところに, 始めて実験動物の 進歩が期待できる”と述べている16).

また, 実験動物と獣医学と題して講演した越智学会長 は“獣医学が, 家畜, いいか劣れば, 人類社会に必要と される合目的な動物を研究する学問であり, 実験動物も また合目的な動物であることを考学ると，実験動物の研 究は獣医学の対象に当然含まれてきてさしつか学ない分
野であるし, 現に一部の研究者はこの分野の学問に専念 している. 今後獣医学研究者が実験動物にどれだけ深く 突進んで行くかは, 社会が実験動物をどれだけ重視し, その基本となる研究をどのように高く評価するかにかか っている”と述べている17).

すでに, 実験動物研究会の発足当初から, 今日にいた るまで, 多くの獣医, 畜産学関係者は, 医学, 薬学, 理 学などの関係分野の専門家と密接な協力の下にその推進 に大きい役割を果してきた，末た，新設された各大学， 国立研究機関, 製薬会社などの実験動物飼育施設におい ては, 獣医, 畜産学関係者がかなり進出してその責任を 果してきている。今後実験動物部門は獣医, 畜産学関係 者にとっては新しい職域ともなる内容を含んでいるの で, 今後の発展が期待されている.

$$
\text { 文献 }
$$

1) 日本医学会動物実験現状調查会：日本に打沙る動 物実験の現状 (1960)，2）日本実験動物研究会, 実験 動物の系統についての委員会 : 実験動物の表示法のとり き(案), 1. マウスについて, 実験動物, 12,169(1963). 3) 田嶋嘉雄 : わが国の実験動物一各機関, 研究者が維 持している動物種，ならびに系統. 実験動物，12，145 (1963). 4) 田嶋嘉雄： S P F 動物について, 実験動 物，13，133 (1964). 5) 宮川正澄：実験動物の無菌 飼育. 日新医学, 42,553 (1955). 6) 田波潤一郎 : ビニール然菌飼育装置と無菌動物に関する 2,3 の問題 について. モダンメデイア， 7，206，259 (1961). 7) 高田敦徳: 実験動物の寄生虫に関する研究, 第 2 報。 、 ウスの寄生虫駆除法の研究, 第 3 報, マウスに寄生する ナナ条虫の駆虫実験. 実験動物, 7, 102 (1958). 8) VoGe, M.: Helminth infections in small laboratory mammals and methods of obtaining a helminth-free Colony. Proc. Animal care panel. 8, 107 (1959). 9) FARris, E.J. \& J. Q. GRIFFITH: The rat in laboratory investigation. 2nd Edition, J.B. Lippincott, Philadelphia (1949). 10) 鈴木 潔: 実験動物のとり扱い方一般, 蛋白質, 核酸, 酵素, 7, 720 (1962).

11) 中尾 健：薬理学研究之実験動物, 医学のあゆ み, 29, 539 (1959). 12) BigGers, J.D. \& ClarinGBOLD, P.J.: Why use inbred lines? Nature, 174, 596(1954). 13) Biggers, J.D., Mclaren, A. \& Michie, D: Variance control in the animal house. Nature, 182, 77(1958). 14). Andervont. H. B.: Incidence of Cancer in mice in relation to numbers caged together. J. Nat. Cancer Inst., 4, 579 (1944). 15) Товасн, E \& Bцоск, H.: A Study of the relationship between behaviour and susceptibility to tuberculosis in rats and mice. Adv. Tuberc. Res., 6, 62(1955). 16) 安東洪次 : 実験動物の世界各国の現状, 医学のあゆ 夕, 29, 527 (1959). 17) 越智勇一: 実験動物と獣医 学, 医学のあゆみ, 29, 534 (1959).

$$
\times \quad \times \quad \times
$$

日獣会誌 19 (1966) 